\section{Soil Applied Maleic Hydrazide Does Not Suppress Tobacco Axillary Bud Growth}

\author{
Matthew C. Vann*
}

\begin{abstract}
With an increasing focus on maleic hydrazide $(\mathrm{MH})$ residues and the need to sufficiently control axillary bud (sucker) growth, fluecured tobacco (Nicotiana tabacum L.) producers would benefit from an alternative to the conventional foliar application method of the plant growth regulator. Research was conducted in four North Carolina environments from 2014 to 2015 to quantify the efficacy of soil applications of $\mathrm{MH}$. Two rates of $\mathrm{MH}$ were selected (2.25 and $4.50 \mathrm{lb}$ a.i./acre) and were applied in combination with one of three sucker control programs: foliar $\mathrm{MH}$ preceded by foliar flumetralin ( $F$ treatment), soil $\mathrm{MH}$ preceded by foliar flumetralin (SF treatment), or soil MH preceded by foliar fatty alcohol (SFA treatment). Ranging from 95 to $100 \%$, sucker suppression was greatest in $\mathrm{F}$ treatments. In two Coastal Plain environments, the control in SF treatments was similar to that of F treatments; however, in the two Piedmont environments, the control was reduced by 30 to $50 \%$. Sucker suppression was lowest in SFA treatments, particularly in the Piedmont environments, thus indicating that flumetralin was the likely source of suppression in SF treatments. No differences were observed between the two $\mathrm{MH}$ application rates evaluated. Given the observations of this study, it is unlikely that a soil application of $\mathrm{MH}$ will serve as an effective sucker control alternative to the standard foliar application used at present by commercial growers.
\end{abstract}

$\mathbf{T}$ obacco (Nicotiana tabacum L.) is a flowering plant with a central, terminal meristem that suppresses the growth of axillary buds (suckers) by hormonal action (Peedin, 1999). At an advanced stage of growth, most commonly 8 to $10 \mathrm{wk}$ after transplanting, the terminal meristem is removed from the plant to increase the yield and quality of cured leaves, as well as to reduce lodging and insect presence (Papenfus, 1987; Fisher et al., 2017). The removal of the terminal meristem is a practice termed as "topping." Topping accelerates the growth and development of suckers (Decker and Seltmann, 1971), which must in turn be manually or chemically removed for maximized leaf yield and quality (Peedin, 1999). Overwhelmingly, chemical sucker control is preferred by US producers due to the high cost and low availability of manual labor (Peedin, 1999).

Of the three classes of suckercide chemistry, maleic hydrazide $(\mathrm{MH})$ is the only one that exhibits true systemic activity (Peedin, 1999; Collins and Hawks, 2013). Once absorbed by the tobacco plant, $\mathrm{MH}$ is freely translocated in both the xylem and phloem to meristems where cell division is then inhibited (Peedin, 1999; Collins and Hawks, 2013). To reduce injury potential to harvestable leaves, $\mathrm{MH}$ is not applied to actively growing plants until the upper two

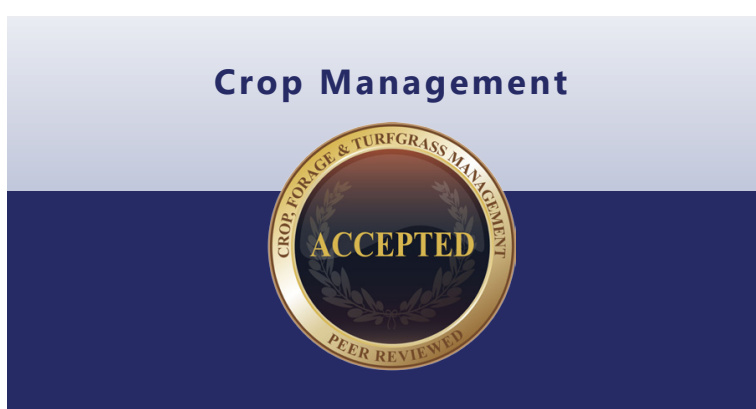

Core Ideas

- Maleic hydrazide residues are a threat to the US tobacco industry.

- Alternative application methods could prove beneficial.

- Root absorption of maleic hydrazide appears to be limited.

M.C. Vann, Dep. of Crop and Soil Sciences, North Carolina State Univ., Raleigh, NC 27695. *Corresponding author (matthew vann@ncsu.edu).

Received 1 July 2017.

Accepted 27 Sept. 2017.

Abbreviations: $\mathrm{F}$ treatment, foliar maleic hydrazide preceded by foliar flumetralin; FA, fatty alcohol; LCPRS Lower Coastal Plain Research Station; MH, maleic hydrazaide; OTRS, Oxford Tobacco Research Station; SF treatment, soil maleic hydrazide preceded by foliar flumetralin; SFA treatment, soil maleic hydrazide preceded by foliar fatty alcohol.

Conversions: For unit conversions relevant to this article, see Table A.

Published in Crop Forage Turfgrass Manage. Volume 3. doi:10.2134/cftm2017.07.0043

(C) 2017 American Society of Agronomy and Crop Science Society of America 5585 Guilford Rd., Madison, WI 53711 All rights reserved. 
Table A. Useful conversions.

\begin{tabular}{lcc}
\hline $\begin{array}{l}\text { To convert Column } 1 \text { to Column 2, } \\
\text { multiply by }\end{array}$ & Column 1 & Column 2 \\
SI Unit \\
1.405 & Suggested Unit & hectare, ha \\
28.4 & acre & kilogram per hectare, $\mathrm{kg} / \mathrm{ha}$ \\
& pound per acre lb/acre & gram, g \\
\hline
\end{tabular}

or three leaves are a minimum of 10 to 12 inches in length (Collins and Hawks, 2013). Prior to MH application, fatty alcohol (FA) contacts and contact-local systemic suckercides (such as butralin or flumetralin) are applied to inhibit sucker development (Fisher et al., 2017). At present, two MH formulations are used in the production of flue-cured tobacco: 1.50 and $2.25 \mathrm{lb}$ a.i./gal (Fisher et al., 2017). Regardless of formulation, recommendations from the North Carolina Cooperative Extension Service suggest that application rates of $\mathrm{MH}$ should not exceed $2.25 \mathrm{lb}$ a.i./acre to minimize cured leaf residues (Fisher et al., 2017). Applications are delivered directly above plants in a concentrated band measuring 18 to 20 inches in width through a solution volume of $50 \mathrm{gal} / \mathrm{acre}$ to ensure sufficient plant coverage and stalk rundown (Fisher et al., 2017). Under normal growing conditions, $\mathrm{MH}$ will suppress sucker growth for $\sim 6$ to $7 \mathrm{wk}$ after application (Collins and Hawks, 2013).

Despite the benefits of $\mathrm{MH}$ application to sucker growth suppression and the reduced cost of production, $\mathrm{MH}$ residues are significantly higher than other pesticides used on tobacco (Collins and Hawks, 2013). Sheets and Nelson (1989) reported that $\mathrm{MH}$ residue levels ranged from undetectable to a high of $351 \mathrm{ppm}$ when $2.25 \mathrm{lb}$ a.i./acre was applied to flue-cured tobacco produced in North Carolina. In addition, of the 163 samples analyzed by Sheets and Nelson, 36\% of the samples exceeded the 80 -ppm residue tolerance limit established by the tobacco industry (Sheets and Nelson, 1989). Maleic hydrazide is a stable compound, resistant to ultraviolet and thermal degradation, and is not volatile, which likely explains its persistence in manufactured tobacco products (Collins and Hawks, 2013). Given the need that exists for the use of $\mathrm{MH}$ in the production of flue-cured tobacco, US producers would benefit from alternative application methods that might prevent vegetative interception of the chemical. One proposed application method is the delivery of $\mathrm{MH}$ to the soil surface through a high solution volume that would promote soil infiltration and root absorption. Root assimilation of $\mathrm{MH}$ has been reported in oats (Avena sativa L.) (Levi and Crafts, 1952), tomato (Solanum lycopersicum L.) (Schoene and Hoffman, 1949; Venezian et al., 2017), and by tobacco seedlings evaluated in greenhouse trials (Hoffman et al., 1962). However, desired results have often proven inconsistent (Venezian et al., 2017) or were achieved through extremely high $\mathrm{MH}$ application rates (Schoene and Hoffman, 1949; Levi and Crafts, 1952; Hoffman et al., 1962). The research contained herein was conducted in 2014 and 2015 to test the hypothesis that an alternative $\mathrm{MH}$ application method (soil delivery) could deliver sucker suppression equivalent to the conventional application method (foliar delivery) in the field production of flue-cured tobacco.

\section{Location Descriptions and Plot Establishment}

Experiments were initiated in 2014 at two locations, the Lower Coastal Plain Research Station (LCPRS) in Kinston, NC $\left(35.297^{\circ} \mathrm{N}, 77.574^{\circ} \mathrm{W}\right)$, and the Oxford Tobacco Research Station (OTRS) in Oxford, NC $\left(36.035^{\circ} \mathrm{N}, 78.610^{\circ} \mathrm{W}\right)$. Research was continued in 2015 at the same research stations, providing four separate environments for treatment evaluation. Treatments were arranged in a randomized complete block design, were replicated four times, and were imposed to individual plots measuring $50 \mathrm{ft}$ in length by four rows in width. All four rows of each plot were treated, with the center two rows used for data collection. Row spacing was 44 and 48 inches at the LCPRS and OTRS, respectively. Planting density was 6000 plants/acre in all environments. Tobacco was produced using recommendations from Fisher (2017), with the exception of treatments imposed.

Application sequence and date for each suckercide are presented in Table 1. All plots were treated with a foliar application of $85 \%$ (a.i.) FA at a $4 \% \mathrm{v} / \mathrm{v}$ concentration when at least half of the plants reached the button stage of flower development. A second foliar FA application was delivered to all plots 6 or $7 \mathrm{~d}$ later at a $5 \% \mathrm{v} / \mathrm{v}$ concentration using the same FA source. A third suckercide application was then delivered $7 \mathrm{~d}$ after the 5\% FA application, with Treatments 1 to 4 receiving flumetralin and Treatments 5 and 6 receiving 5\% v/v FA. Flumetralin provides residual sucker suppression (Fisher et al., 2017); therefore, FA was applied in Treatments 5 and 6 to quantify the true effect of $\mathrm{MH}$. After harvest of the lower five tobacco leaves, $\mathrm{MH}$ was foliar applied in Treatments 1 and 2, and soil was applied along both sides of each plot row in Treatments 3 to 6 . All suckercides were applied using a $\mathrm{CO}_{2}$-pressurized backpack sprayer calibrated at a delivery volume of 50 gal/acre. Foliar applications were delivered with a standard 20-inch, three-nozzle boom that contained a TG3-TG5-TG3 (TeeJet Technologies) nozzle arrangement. The outside two nozzles were oriented inward at $45^{\circ}$ to promote stalk rundown. Soil applications were delivered with a wand containing a single TG5 nozzle calibrated to deliver 25 gal solution/acre. Each side of the plot row adjacent to tobacco in the soil-applied treatments was treated to provide a total solution delivery volume of $50 \mathrm{gal} /$ acre. Maleic hydrazide will not control suckers $>1$ inch in length (Fisher et al., 2017); therefore, prior to $\mathrm{MH}$ application, suckers measuring $>1$ inch in length were hand removed to provide accuracy in quantifying sucker suppression. Two rates of $\mathrm{MH}$ were also evaluated within each application method: $2.25(1 \times)$ and $4.50(2 \times) \mathrm{lb}$ a.i./acre. Treatments are defined in Tables 2 to 6 . A negative 
control treatment that was topped, but not hand suckered or chemically treated, was included within each environment.

\section{Data Collection and Analysis Sucker Number, Sucker Weight, and Percentage Control}

After the final harvest, all suckers from 20 plants per plot (10/row) were removed, counted, and weighed while green using the methods of Yelverton et al. (1993).

\section{Yield, Quality, and Value}

Cured leaves were weighed from the center two rows of each plot to determine yield and were assigned a USDA grade. Each grade describes leaf maturity and ripeness and has an associated index value and price (Bowman et al., 1988). Crop value was determined using a combination of leaf yield and quality with price indices reported by Fisher et al. (2017).

\section{Data Analysis}

Data were subjected to ANOVA using the PROC MIXED procedure in SAS 9.4 (SAS Institute, 2013). Treatment was considered to be fixed factor, whereas replication was considered

Table 1. Suckercide classification, tradename, and application date within each environment.

\begin{tabular}{|c|c|c|c|c|c|}
\hline Classification & Tradename & LCPRS+ 2014 & LCPRS 2015 & OTRS $\neq 2014$ & OTRS 2015 \\
\hline Fatty alcohol & Off-Shoot-T§ & 11 July & 10 July & 23 July & 15 July \\
\hline Fatty alcohol & Off-Shoot-T & 17 July & 16 July & 28 July & 21 July \\
\hline Flumetralin & Prime+II & 23 July & 22 July & 1 Aug. & 27 July \\
\hline Maleic hydrazide & Royal MH-30 XTRA§ & 29 July & 28 July & 08 Aug. & 12 Aug. \\
\hline
\end{tabular}

+ LCPRS, Lower Coastal Plain Research Station.

‡ OTRS, Oxford Tobacco Research Station.

$\S$ Arysta LifeScience, Cary, NC.

II Syngenta Crop Protection, Greensboro, NC in 2015.

Table 2. Effect of maleic hydrazide (MH) application method on the number of suckers per plant in four North Carolina environments. ${ }^{\dagger}$

\begin{tabular}{|c|c|c|c|c|c|c|}
\hline Treatment $\ddagger$ & $\begin{array}{l}\text { Application } \\
\text { method }\end{array}$ & Rate & LCPRS§ 2014 & LCPRS 2015 & OTRST 2014 & OTRS 2015 \\
\hline \multirow[b]{2}{*}{ 1. FA } & \multicolumn{2}{|r|}{$\mathrm{lb}$ a.i./acre } & \multicolumn{4}{|c|}{ _ suckers/plant - } \\
\hline & Foliar & 12.04 & $0.18 \mathrm{c}$ & $0.03 \mathrm{~d}$ & $0.03 \mathrm{c}$ & $0.05 \mathrm{c}$ \\
\hline FA & Foliar & 15.05 & & & & \\
\hline Flum. & Foliar & 0.60 & & & & \\
\hline $\mathrm{MH}$ & Foliar & 2.25 & & & & \\
\hline 2. FA & Foliar & 12.04 & $0.15 c$ & $0.01 \mathrm{~d}$ & $0.23 \mathrm{bc}$ & $-\#$ \\
\hline FA & Foliar & 15.05 & & & & \\
\hline Flum. & Foliar & 0.60 & & & & \\
\hline $\mathrm{MH}$ & Foliar & 4.50 & & & & \\
\hline 3. FA & Foliar & 12.04 & $0.30 \mathrm{c}$ & $0.73 \mathrm{bc}$ & $1.08 \mathrm{~b}$ & $3.30 \mathrm{~b}$ \\
\hline FA & Foliar & 15.05 & & & & \\
\hline Flum. & Foliar & 0.60 & & & & \\
\hline $\mathrm{MH}$ & Soil & 2.25 & & & & \\
\hline 4. FA & Foliar & 12.04 & $0.18 \mathrm{c}$ & $0.23 \mathrm{~cd}$ & $1.03 \mathrm{~b}$ & $2.95 \mathrm{~b}$ \\
\hline FA & Foliar & 15.05 & & & & \\
\hline Flum. & Foliar & 0.60 & & & & \\
\hline $\mathrm{MH}$ & Soil & 4.50 & & & & \\
\hline 5. FA & Foliar & 12.04 & $1.23 \mathrm{~b}$ & $1.35 \mathrm{~b}$ & $3.75 \mathrm{a}$ & $4.90 \mathrm{a}$ \\
\hline FA & Foliar & 15.05 & & & & \\
\hline Flum. & Foliar & 0.60 & & & & \\
\hline $\mathrm{MH}$ & Soil & 4.50 & & & & \\
\hline 6. TNS & - & - & $4.03 \mathrm{a}$ & $4.00 \mathrm{a}$ & $3.00 \mathrm{a}$ & $5.90 \mathrm{a}$ \\
\hline$P>F$ & & & $<0.0001$ & $<0.0001$ & $<0.0001$ & $<0.0001$ \\
\hline
\end{tabular}

+ Treatment means followed by the same letter within the same environment are not significantly different at the $\alpha=0.05$ level.

$\ddagger$ FA, fatty alcohol; Flum., flumetralin; TNS, topped not suckered.

$\S$ LCPRS, Lower Coastal Plain Research Station.

II OTRS, Oxford Tobacco Research Station.

\# Treatment excluded from analysis due to plot loss. 
Table 3. Effect of maleic hydrazide $(\mathrm{MH})$ application method on the green weight of suckers per plant in four North Carolina environments. +

\begin{tabular}{|c|c|c|c|c|c|c|}
\hline Treatment $\ddagger$ & $\begin{array}{l}\text { Application } \\
\text { method }\end{array}$ & Rate & LCPRS§ 2014 & LCPRS 2015 & OTRST 2014 & OTRS 2015 \\
\hline & & lb a.i./acre & 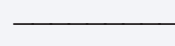 & $-{ }^{2}$ & $t$ & 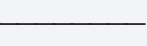 \\
\hline 1. FA & Foliar & 12.04 & $0.0018 \mathrm{~b}$ & $0.0004 \mathrm{~d}$ & $0.0004 \mathrm{~d}$ & $0.0014 \mathrm{~d}$ \\
\hline FA & Foliar & 15.05 & & & & \\
\hline Flum. & Foliar & 0.60 & & & & \\
\hline $\mathrm{MH}$ & Foliar & 2.25 & & & & \\
\hline 2. FA & Foliar & 12.04 & $0.0014 \mathrm{~b}$ & $0.0000 \mathrm{~d}$ & $0.0011 \mathrm{~cd}$ & -\# \\
\hline FA & Foliar & 15.05 & & & & \\
\hline Flum. & Foliar & 0.60 & & & & \\
\hline $\mathrm{MH}$ & Foliar & 4.50 & & & & \\
\hline 3. FA & Foliar & 12.04 & $0.0028 \mathrm{~b}$ & $0.0060 \mathrm{bc}$ & $0.0155 \mathrm{~b}$ & $0.0243 \mathrm{c}$ \\
\hline FA & Foliar & 15.05 & & & & \\
\hline Flum. & Foliar & 0.60 & & & & \\
\hline $\mathrm{MH}$ & Soil & 2.25 & & & & \\
\hline 4. FA & Foliar & 12.04 & $0.0021 \mathrm{~b}$ & $0.0035 \mathrm{~cd}$ & $0.0138 \mathrm{bc}$ & $0.0254 \mathrm{c}$ \\
\hline FA & Foliar & 15.05 & & & & \\
\hline Flum. & Foliar & 0.60 & & & & \\
\hline $\mathrm{MH}$ & Soil & 4.50 & & & & \\
\hline 5. FA & Foliar & 12.04 & $0.0053 \mathrm{~b}$ & $0.0099 \mathrm{~b}$ & $0.0413 \mathrm{a}$ & $0.0476 \mathrm{~b}$ \\
\hline FA & Foliar & 15.05 & & & & \\
\hline Flum. & Foliar & 0.60 & & & & \\
\hline $\mathrm{MH}$ & Soil & 2.25 & & & & \\
\hline 6. FA & Foliar & 12.04 & $0.0046 \mathrm{~b}$ & $0.0106 \mathrm{~b}$ & $0.0384 \mathrm{a}$ & $0.0596 \mathrm{ab}$ \\
\hline FA & Foliar & 15.05 & & & & \\
\hline Flum. & Foliar & 0.60 & & & & \\
\hline $\mathrm{MH}$ & Soil & 4.50 & & & & \\
\hline 7. TNS & - & - & $0.0363 \mathrm{a}$ & $0.0526 \mathrm{a}$ & $0.0339 a$ & $0.0801 \mathrm{a}$ \\
\hline$P>F$ & & & $<0.0001$ & $<0.0001$ & $<0.0001$ & $<0.0001$ \\
\hline
\end{tabular}

+ Treatment means followed by the same letter within the same environment are not significantly different at the $\alpha=0.05$ level.

‡ FA, fatty alcohol; Flum., flumetralin; TNS, topped not suckered.

$\S$ LCPRS, Lower Coastal Plain Research Station.

II OTRS, Oxford Tobacco Research Station.

\# Treatment excluded from analysis due to plot los.

a random factor. Due to significant treatment $\times$ environment interactions, data were analyzed by individual growing environment. Treatment means were reported using least square means. Means were separated using Fisher's protected LSD at $P \leq 0.05$.

\section{Sucker Number}

Foliar (F treatment, foliar MH preceded by foliar flumetralin) applications of $\mathrm{MH}$ resulted in the lowest number of suckers per plant (Table 2). Sucker number increased with SF (soil MH preceded by foliar flumetralin) and SFA (soil MH preceded by foliar FA) treatments when compared with F treatments. Among all treatments, SFA consistently produced the highest number of suckers (1.0-5.9/plant) (Table 2). In both OTRS environments, the number of suckers in SFA treatments were not different from the topped, not-suckered control treatment (Table 2). In general, differences between the $1 \times$ and $2 \times$ $\mathrm{MH}$ application rates were not significant (Table 2).

\section{Sucker Weight}

In three of the four environments (LCPRS 2015, OTRS 2014, and OTRS 2015), F treatments produced suckers with the smallest mass (Table 3). In each of those environments, sucker mass increased by 10 to 17 times in SF treatments when compared with F treatments (Table 3). Sucker mass was further increased in SFA treatments (Table 3). As was noted in regards to sucker number, differences between the $1 \times$ and $2 \times \mathrm{MH}$ application rates were not significant in most environments (Table 2). A reduction in sucker mass was noted at the $2 \times$ rate at LCPRS 2015 in SF treatments; however, the reduction in sucker mass was $0.07 \mathrm{~g} / \mathrm{plant}$, which is not likely to have a significant agronomic effect (Table 3). Yelverton et al. (1993) suggests that sucker weight might be a more effective measurement to quantify sucker control than sucker number per plant because many small suckers on a single plant are not as detrimental to yield as a few large suckers. 
Table 4. Effect of maleic hydrazide (MH) application method on sucker suppression in four North Carolina environmentst.

\begin{tabular}{|c|c|c|c|c|c|c|}
\hline Treatment $\ddagger$ & $\begin{array}{l}\text { Application } \\
\text { method }\end{array}$ & Rate & LCPRS§ 2014 & LCPRS 2015 & OTRSI 2014 & OTRS 2015 \\
\hline & & lb a.i./acre & 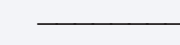 & 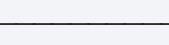 & 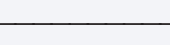 & - \\
\hline 1. FA & Foliar & 12.04 & 95 a & $99 \mathrm{ab}$ & $100 \mathrm{a}$ & $98 \mathrm{a}$ \\
\hline FA & Foliar & 15.05 & & & & \\
\hline Flum. & Foliar & 0.60 & & & & \\
\hline $\mathrm{MH}$ & Foliar & 2.25 & & & & \\
\hline 2. FA & Foliar & 12.04 & $95 \mathrm{a}$ & $100 \mathrm{a}$ & $97 \mathrm{a}$ & $-\#$ \\
\hline FA & Foliar & 15.05 & & & & \\
\hline Flum. & Foliar & 0.60 & & & & \\
\hline $\mathrm{MH}$ & Foliar & 4.50 & & & & \\
\hline 3. FA & Foliar & 12.04 & $93 \mathrm{ab}$ & $89 c$ & $50 \mathrm{~b}$ & $67 \mathrm{~b}$ \\
\hline FA & Foliar & 15.05 & & & & \\
\hline Flum. & Foliar & 0.60 & & & & \\
\hline $\mathrm{MH}$ & Soil & 2.25 & & & & \\
\hline 4. FA & Foliar & 12.04 & $95 \mathrm{a}$ & $93 \mathrm{bc}$ & $55 \mathrm{ab}$ & $69 \mathrm{~b}$ \\
\hline FA & Foliar & 15.05 & & & & \\
\hline Flum. & Foliar & 0.60 & & & & \\
\hline $\mathrm{MH}$ & Soil & 4.50 & & & & \\
\hline 5. FA & Foliar & 12.04 & $86 \mathrm{~b}$ & $81 \mathrm{~d}$ & $-29 c$ & $40 \mathrm{c}$ \\
\hline FA & Foliar & 15.05 & & & & \\
\hline Flum. & Foliar & 0.60 & & & & \\
\hline $\mathrm{MH}$ & Soil & 2.25 & & & & \\
\hline 6. FA & Foliar & 12.04 & $86 \mathrm{~b}$ & $80 \mathrm{~d}$ & $-26 c$ & $20 \mathrm{~cd}$ \\
\hline FA & Foliar & 15.05 & & & & \\
\hline Flum. & Foliar & 0.60 & & & & \\
\hline $\mathrm{MH}$ & Soil & 4.50 & & & & \\
\hline 7. TNS & - & - & $0 \mathrm{c}$ & $0 \mathrm{e}$ & $0 \mathrm{c}$ & $0 \mathrm{~d}$ \\
\hline$P>F$ & & & $<0.0001$ & $<0.0001$ & $<0.0001$ & $<0.0001$ \\
\hline
\end{tabular}

+ Treatment means followed by the same letter within the same environment are not significantly different at the $\alpha=0.05$ level.

$\ddagger$ FA, fatty alcohol; Flum., flumetralin; TNS, topped not suckered.

$\S$ LCPRS, Lower Coastal Plain Research Station.

II OTRS, Oxford Tobacco Research Station.

\# Treatment excluded from analysis due to plot loss.

\section{Percentage Control}

Sucker control in $\mathrm{F}$ treatments ranged from 95 to $100 \%$ (Table 4), which is comparable with results reported by Fisher et al. (2017). In the OTRS 2014, OTRS 2015, and LCPRS 2015 environments, SF and SFA treatments reduced sucker control relative to F treatments (Table 4). Sucker control was consistently lowest in SFA treatments. In the OTRS 2014 environment, control in SFA treatments was less than that of the topped, not-suckered control (Table 4). At the time of rating, suckers in the topped, not-suckered control treatment were mature and beginning to senesce, whereas suckers in SFA treatments were immature and actively growing. This observation indicates that sucker growth was delayed in SFA treatments, most likely due to the foliar FA applications that preceded $\mathrm{MH}$ application to the soil surface.

Ultimately, neither the SF nor SFA treatments consistently provided an acceptable level of sucker suppression, due to insufficient $\mathrm{MH}$ assimilation. Maleic hydrazide has been reported to rapidly disappear from the soil (Hoffman et al., 1962; Helweg, 1975). Further investigations of MH disappearance suggest that specific surface area, clay content, and $\mathrm{pH}$ influence MH adsorption by soils (Hermosin et al., 1987, 1991). Given that the soil types used for this study were classified as Helena sandy loam (fine, mixed, semiactive, thermic Aquic Hapludults) at the OTRS and Goldsboro loamy sand (fine-loamy, siliceous, subactive, thermic Aquic Paleudults) at the LCPRS, it is probable that the clay fraction of the soil profile might be the factor most inhibiting of $\mathrm{MH}$ assimilation by tobacco.

Conclusions similar to those reported in this study have been documented in tobacco and other crops. Hoffman et al. (1962) observed stunted tobacco growth in greenhouse studies designed to quantify $\mathrm{MH}$ residues in seedlings exposed to increasing $\mathrm{MH}$ concentrations in treated soil. Hoffman et al. (1962) further noted that stunting was alleviated over time, and that $\mathrm{MH}$ residues were only detected $6 \mathrm{wk}$ after seeding 
Table 5. Effect of maleic hydrazide (MH) application method on cured leaf yield in four North Carolina environmentst.

\begin{tabular}{|c|c|c|c|c|c|c|}
\hline Treatment $\ddagger$ & $\begin{array}{l}\text { Application } \\
\text { method }\end{array}$ & Rate & LCPRS§ 2014 & LCPRS 2015 & OTRSI 2014 & OTRS 2015 \\
\hline & & lb a.i./acre & + & -1 & 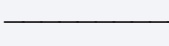 & - \\
\hline 1. FA & Foliar & 12.04 & 2429 a & 2948 a & 2971 a-c & 3884 a \\
\hline FA & Foliar & 15.05 & & & & \\
\hline Flum. & Foliar & 0.60 & & & & \\
\hline $\mathrm{MH}$ & Foliar & 2.25 & & & & \\
\hline 2. FA & Foliar & 12.04 & 2366 a & 2857 a & $3063 a b$ & $-\#$ \\
\hline FA & Foliar & 15.05 & & & & \\
\hline Flum. & Foliar & 0.60 & & & & \\
\hline $\mathrm{MH}$ & Foliar & 4.50 & & & & \\
\hline 3. FA & Foliar & 12.04 & 2709 a & 2696 a & $3252 \mathrm{ab}$ & 3471 a \\
\hline FA & Foliar & 15.05 & & & & \\
\hline Flum. & Foliar & 0.60 & & & & \\
\hline $\mathrm{MH}$ & Soil & 2.25 & & & & \\
\hline 4. FA & Foliar & 12.04 & $2419 a$ & $2675 a$ & $3013 \mathrm{ab}$ & 3506 a \\
\hline FA & Foliar & 15.05 & & & & \\
\hline Flum. & Foliar & 0.60 & & & & \\
\hline $\mathrm{MH}$ & Soil & 4.50 & & & & \\
\hline 5. FA & Foliar & 12.04 & 2477 a & $2606 a$ & 2810 bc & 3169 a \\
\hline FA & Foliar & 15.05 & & & & \\
\hline Flum. & Foliar & 0.60 & & & & \\
\hline $\mathrm{MH}$ & Soil & 2.25 & & & & \\
\hline 6. FA & Foliar & 12.04 & $2620 \mathrm{a}$ & 2585 a & $3283 a$ & 3446 a \\
\hline FA & Foliar & 15.05 & & & & \\
\hline Flum. & Foliar & 0.60 & & & & \\
\hline $\mathrm{MH}$ & Soil & 4.50 & & & & \\
\hline 7. TNS & - & - & $1723 \mathrm{~b}$ & $1888 \mathrm{~b}$ & 2547 c & $3344 \mathrm{a}$ \\
\hline$P>F$ & & & $<0.0001$ & 0.0043 & 0.0086 & 0.1553 \\
\hline
\end{tabular}

t Treatment means followed by the same letter within the same environment are not significantly different at the $\alpha=0.05$ level.

$\ddagger$ FA, fatty alcohol; Flum., flumetralin; TNS, topped not suckered.

$\S$ LCPRS, Lower Coastal Plain Research Station.

II OTRS, Oxford Tobacco Research Station.

\# Treatment excluded from analysis due to plot loss.

in the highest treatment concentration, which represented a $5 \times$ increase above the standard application rate. Venezian et al. (2017) reported inconsistent findings where drip applications of $\mathrm{MH}$ were used to control Egyptian broomrape (Orobanche aegyptiaca Pers.) in tomato production. Venezian et al. (2017) concluded that foliar applications were more favorable than drip application due to soil chemical and physical characteristics that are likely to adsorb or inactivate $\mathrm{MH}$.

\section{Yield, Quality, and Value}

Tobacco yield was lowest in the topped, not-suckered control treatment in three environments (Table 5). In both LCPRS environments, yield was not affected by $\mathrm{MH}$ application program (Table 5). Sucker control was $\geq 80 \%$ (Table 4 ) in those environments and is the likely factor contributing to similar yield among treatments. Alternatively, in the OTRS 2014 environment, differences in leaf yield were observed, but general trends are difficult to establish when yield is compared with percentage control. For example, treatments with the lowest percentage sucker control (SFA, $2 \times \mathrm{MH}$ ) yielded similar to F treatments (Table 5). Given these observations, it is probable that sucker regrowth after suckercide applications was delayed long enough for tobacco yield to remain unaffected. Tobacco quality was not affected by treatments (data not shown), although crop value was greatest in treatments with the highest yields (Table 6).

\section{Conclusions}

Results indicate that soil applications of $\mathrm{MH}$ are unlikely to provide sucker suppression at a level of control that is acceptable to producers and industry. In soil-applied treatments (SF and SFA), suppression was generally lowest when FA was applied instead of flumetralin. This observation indicates that sucker growth suppression in SF treatments was a result of flumetralin application and not $\mathrm{MH}$. 
Table 6. Effect of maleic hydrazide (MH) application method on cured leaf value in four North Carolina environmentst.

\begin{tabular}{|c|c|c|c|c|c|c|}
\hline Treatment $\neq$ & $\begin{array}{l}\text { Application } \\
\text { method }\end{array}$ & Rate & LCPRS§ 2014 & LCPRS 2015 & OTRSI 2014 & $\begin{array}{l}\text { Application } \\
\text { method }\end{array}$ \\
\hline & & $\mathrm{lb}$ a.i./acre & & $-\mathrm{U}$ & 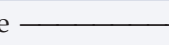 & \\
\hline 1. FA & Foliar & 12.04 & $4113 \mathrm{a}$ & $5311 \mathrm{a}$ & 5231 bc & $7495 \mathrm{a}$ \\
\hline FA & Foliar & 15.05 & & & & \\
\hline Flum. & Foliar & 0.60 & & & & \\
\hline $\mathrm{MH}$ & Foliar & 2.25 & & & & \\
\hline 2. FA & Foliar & 12.04 & $3990 \mathrm{a}$ & $5213 \mathrm{a}$ & $5711 \mathrm{ab}$ & -\# \\
\hline FA & Foliar & 15.05 & & & & \\
\hline Flum. & Foliar & 0.60 & & & & \\
\hline MH & Foliar & 4.50 & & & & \\
\hline 3. FA & Foliar & 12.04 & 4112 a & $4961 \mathrm{a}$ & $6197 a$ & $6668 \mathrm{a}$ \\
\hline FA & Foliar & 15.05 & & & & \\
\hline Flum. & Foliar & 0.60 & & & & \\
\hline $\mathrm{MH}$ & Soil & 2.25 & & & & \\
\hline 4. FA & Foliar & 12.04 & 4023 a & 4945 a & $5597 \mathrm{ab}$ & $6637 \mathrm{a}$ \\
\hline FA & Foliar & 15.05 & & & & \\
\hline Flum. & Foliar & 0.60 & & & & \\
\hline $\mathrm{MH}$ & Soil & 4.50 & & & & \\
\hline 5. FA & Foliar & 12.04 & $4391 \mathrm{a}$ & 4779 a & 5298 a-c & $6098 a$ \\
\hline FA & Foliar & 15.05 & & & & \\
\hline Flum. & Foliar & 0.60 & & & & \\
\hline $\mathrm{MH}$ & Soil & 2.25 & & & & \\
\hline 6. FA & Foliar & 12.04 & $4251 \mathrm{a}$ & $4633 a$ & $6194 \mathrm{a}$ & $6571 \mathrm{a}$ \\
\hline FA & Foliar & 15.05 & & & & \\
\hline Flum. & Foliar & 0.60 & & & & \\
\hline $\mathrm{MH}$ & Soil & 4.50 & & & & \\
\hline 7. TNS & - & - & $2891 \mathrm{~b}$ & $3455 \mathrm{~b}$ & $4626 c$ & $6472 \mathrm{a}$ \\
\hline$P>F$ & & & 0.0029 & 0.0025 & 0.0257 & 0.1556 \\
\hline
\end{tabular}

+ Treatment means followed by the same letter within the same environment are not significantly different at the $\alpha=0.05$ level.

$\ddagger$ FA, fatty alcohol; Flum., flumetralin; TNS, topped not suckered.

$\S$ LCPRS, Lower Coastal Plain Research Station.

II OTRS, Oxford Tobacco Research Station.

\# Treatment excluded from analysis due to plot loss.

Sucker suppression was not improved as $\mathrm{MH}$ application rate increased from 2.25 to $4.50 \mathrm{lb}$ a.i./acre, which reinforces the recommendation that 1 gal/acre of 2.25 - 1 b a.i./gal product is sufficient for acceptable sucker control. Lastly, it is probable that the chosen solution volume of 50 gal/acre was not sufficient for immediate soil infiltration and root exposure; therefore, further research is warranted to investigate the effect of application volume. At present, tobacco producers should apply $\mathrm{MH}$ to tobacco foliage at rates recommended by the North Carolina Cooperative Extension Service in an attempt to minimize $\mathrm{MH}$ exposure to leaves and, therefore, limit the subsequent residues that might remain.

\section{References}

Bowman, D.T., A.G. Tart, E.A. Wernsman, and T.C. Corbin. 1988. Revised North Carolina grade index for flue-cured tobacco. Tobacco Sci. 32:39-40.

Collins, W.K., and S.N. Hawks. 2013. Topping and suckering. In: W.K. Collins, editor, Principles of flue-cured tobacco production. 2nd ed. Hawks \& Collins, Raleigh, NC. p. 78-87.
Decker, R.D., and H. Seltmann. 1971. Axillary bud development in Nicotiana tabacum L. after topping. Tobacco Sci. 14:144-148.

Fisher, L.R., editor. 2017. 2017 North Carolina State University fluecured tobacco production guide (AG-187 (Revised)). North Carolina Coop. Ext. Serv., Raleigh, NC.

Fisher, L.R., M.C. Vann, J.A. Priest, D.S. Whitley, J. Cheek, and R. Seagroves. 2017. Topping, managing suckers, and using ethephon. In: L.R. Fisher, editor, 2017 North Carolina State University flue-cured tobacco production guide (AG-187 (Revised)). North Carolina Coop. Ext. Serv., Raleigh, NC. p. 97-118.

Helweg, A. 1975. Degradation of ${ }^{14} \mathrm{C}$-labelled maleic hydrazide in soil as influenced by sterilization, concentration, and pretreatment. Weed Res. 15:53-58. doi:10.1111/j.1365-3180.1975.tb01096.x

Hermosin, M.C., J. Cornejo, and J.L. Perez Rodriguez. 1987. Adsorption and desorption of maleic hydrazide as a function of soil properties. Soil Sci. 144:250-256. doi:10.1097/00010694198710000-00003

Hermosin, M.C., I. Roldan, and J. Cornejo. 1991. Adsorption-desorption of maleic hydrazide on mineral soil components. J. Environ. Sci. Health Part B 26:165-183. doi:10.1080/03601239109372729 
Hoffman, I., E.V. Parups, and R.B. Carson. 1962. Growth regulator residues, analysis for maleic hydrazide. Part I. Detection and determination in dried green tobacco leaves and suckers. Part II. Determination and persistence in soils. J. Agric. Food Chem. 10:453-455. doi:10.1021/jf60124a005

Levi, E., and S. Crafts. 1952. Toxicity of maleic hydrazide in California soils. Hilgardia 21:431-463. doi:10.3733/hilg.v21n16p431

Papenfus, H.D. 1987. Some aspects of stress management in tobacco. Rec. Adv. Tobacco Sci. 13:27-55.

Peedin, G.F. 1999. Production practices: Flue-cured tobacco. In: D.L. Davis and M.T. Nielsen, editors, Tobacco production, chemistry, and technology. Blackwell Science, Malden, MA. p. 104-142.

SAS Institute. 2013. The SAS system for Windows. Release 9.4. SAS Inst., Cary, NC.
Schoene, D.L., and O.L. Hoffman. 1949. Maleic hydrazide, a unique growth regulant. Science 109(:588-590. doi:10.1126/ science.109.2841.588-a

Sheets, T.J., and L.A. Nelson. 1989. Variation of MH residues on flue-cured tobacco. Tobacco Sci. 33:5-8.

Venezian, A., E. Dor, G. Achdari, D. Plakhine, E. Smirnov, and J. Hershenhorn. 2017. The influence of the plant growth regulator maleic hydrazide on Egyptian broomrape early developmental stages and its control efficacy in tomato under greenhouse and field conditions. Front. Plant Sci. 8:691. doi:10.3389/ fpls.2017.00691

Yelverton, F.H., D.T. Gooden, T.D. Reed, M.G. Stephenson, and E.B. Whitty. 1993. The effects of butralin on sucker control in fluecured tobacco. Tobacco Sci. 37:54-58. 